\title{
Mudanças cíclicas em português no contexto da evolução das línguas românicas ${ }^{1}$
}

\section{Cyclic changes in Portuguese in the context of the evolution of the Romance languages}

JAN Hricsina [Jan.hricsina@ff.cuni.cz]

Univerzita Karlova, República Checa

\section{RESUMO:}

O objetivo do presente artigo é mostrar algumas mudanças que ocorreram no plano fonológico na fase mais antiga da história do Português ou ainda mais cedo (no Latim Vulgar) e que reapareceram mais tarde na evolução da mesma língua. Estas mudanças cíclicas são as seguintes: evolução das consoantes líquidas / / e /l/, lenição das oclusivas sonoras /b/,/d/ e /g/, queda da sibilante /s/ em coda e queda da oclusiva nasal $/ \mathrm{n} /$ em posição intervocálica. Estes fenómenos estão relacionados aos idênticos ou semelhantes ocorridos noutras línguas românicas.

\section{Palavras-chave:}

Mudança linguística cíclica; linguística diacrónica; Português; línguas românicas; fonologia

\begin{abstract}
:
The purpose of this article is to show some changes that occurred in the phonological plan in the earliest stage of the evolution of Portuguese or even earlier (in Vulgar Latin), and reappeared later in the evolution of the same language. These cyclical changes are: the evolution of liquid consonants $/ \mathrm{f} / \mathrm{and} / \mathrm{l} /$, the lenition of voiced occlusives /b/, /d/ and /g/, the disappearance of the sibilant /s/ in syllabic coda and the disappearance of the nasal occlusive /n/ in intervocalic position. These phenomena are related to identical or similar processes that have occured in other Romance languages.
\end{abstract}

\section{KEYWORDS:}

Cyclic linguistic change; diachronic linguistics; Portuguese; Romance languages; phonology

RECEBIDO 2016-01-31; ACEITE 2016-04-19

1 Este artigo faz parte do projeto “Program rozvoje vědních oblastí na Univerzitě Karlově č. P10 Lingvistika”, subprograma "Románské jazyky ve světle jazykových korpusư". 


\section{Introdução}

O objetivo do presente artigo é mostrar algumas mudanças ${ }^{2}$ que ocorreram no plano fonológico na fase mais antiga da história do Português ou ainda mais cedo (no Latim Vulgar) e que reapareceram mais tarde na evolução da mesma língua. Tendo em conta o aspeto cíclico destes processos, podemos denominá-los mudanças cíclicas. Neste texto, propõe-se também relacionar estas mudanças cíclicas portuguesas aos processos evolutivos idênticos ou semelhantes operados noutras línguas românicas.

No primeiro capítulo do estudo, resumiremos os princípios gerais da mudança linguística, documentando-os com os exemplos da evolução do Português ou doutras línguas românicas. Prosseguiremos com a análise de vários tipos de mudanças cíclicas: evolução das consoantes líquidas $/ \mathrm{f} / \mathrm{e} / \mathrm{l} /$, lenição das oclusivas sonoras $/ \mathrm{b} /$, /d/ e /g/, enfraquecimento da pronúncia da sibilante /s/ e queda da oclusiva nasal /n/ em posição intervocálica. Em cada capítulo apresentar-se-á primeiro a evolução do fonema respetivo do Latim Vulgar até ao Português Moderno, seguir-se-á a análise da situação do fenómeno semelhante na história doutras línguas românicas e, no final do capítulo, apontaremos para as relações eventuais entre o Português e outras línguas neolatinas. No final do artigo, concluiremos os resultados das nossas análises.

\section{Mudança linguística}

Podemos começar este capítulo com uma constatação que talvez possa parecer banal: todas as línguas vivas mudam ${ }^{3}$. Praticamente não existe nenhuma língua que não esteja em fase duma certa transformação ou de movimento. Em cada língua viva, há sempre vários fenómenos que estão em processo de evolução. Tomemos o exemplo do Português atual em que podemos observar várias mudanças em curso que ocorrem em todos os subsistemas linguísticos. Ao nível fonético, ultimamente temos deparado com uma transformação do subsistema das líquidas vibrantes e verberantes ${ }^{4} / \mathrm{r} /$, /R/ e / $/$. Em Portugal, há cada vez mais falantes que pronunciam em vez da vibrante múltipla alveolar $/ \mathrm{r} /$ um outro tipo de alofone. $\mathrm{O}$ alofone mais frequente é a fricativa uvular sonora / $\mathrm{s} /$. Além desta mudança, que tem ocorrido durante todo o século XX e continua no século atual, pode observar-se outro processo que terá começado só há alguns anos: é a variação da líquida verberante /r/ que é pronunciada por certos falantes, nomeadamente mulheres jovens, como verberante retroflexiva $/ \mathrm{r}$. Esta variante aparece principalmente em posição de coda no final da palavra (Veloso 2015: 331).

2 As mudanças não serão tratadas com todos os pormenores. O nosso objetivo consiste principalmente em mostrar o seu aspeto cíclico e apontar para algumas relações entre o Português e outras línguas românicas.

3 Pelas línguas vivas (ou naturais) entendemos as línguas que se usam na comunicação quotidiana e que servem de línguas maternas numa certa comunidade ou país. A este conceito opõe-se a categoria das assim chamadas línguas artificiais que se caraterizam pelo facto de terem sido geralmente construídas por um grupo de pessoas limitado e que são utilizadas nomeadamente em domínios científicos ou tecnológicos.

4 A verberante é uma consoante que se pronuncia como contacto rápido de dois órgãos articulatórios. O termo inglês é tap ou flap. 
Ao nível morfossintático, ultimamente tem-se reparado numa confusão no emprego das formas dos particípios duplos em Português. Foram observadas várias tendências que se opõem às regras tradicionais aplicadas ao uso destes particípios. Há vários verbos em que se utilizam só os particípios irregulares (pago, gasto, entregue), mas há também outros que usam as duas formas duma maneira incorreta (ter morto, ter aceite) (Mateus \& Cardeira 2007: 74).

Ao nível sintático, podemos mencionar o caso das orações relativas introduzidas pelo pronome que que deve ser precedido por uma preposição se o respetivo verbo a exige. No Português atual, ocorre frequentemente a supressão da preposição ${ }^{5}$ (É o vinho [de] que gosto mais.) (Peres \& Móia 1995: 292).

Ao nível do léxico, em qualquer língua aparecem quase cada dia novas palavras que são de vários tipos. Pode tratar-se de neologismos, de palavras derivadas ou de estrangeirismos. Hoje em dia, o Português, como outras línguas vivas, está invadido por muitas palavras inglesas como por exemplo roaming, download ou boys band.

Observando a evolução linguística de várias línguas, deparamos com o facto de o ritmo de mudanças linguísticas não ser idêntico em todos os subsistemas de língua. Ao contrário, cada plano linguístico tem o seu próprio ritmo de evolução que difere dos outros planos de língua (Zavadil 1998: 11-14). As transformações mais rápidas ocorrem no subsistema lexical de língua. Já vimos que é com uma frequência bastante elevada que nascem novas palavras (ou são importadas doutras línguas) ou ao contrário, outras palavras deixam de ser usadas e desaparecem do léxico ativo duma língua. O plano lexical reage depressa às transformações da sociedade, à evolução científica (novos termos técnicos) ou simplesmente ao gosto dos falantes duma língua. O léxico de língua representa, assim, o plano linguístico mais sensível às mudanças extralinguísticas.

Muito mais lentas são as transformações operadas no subsistema fonológico duma língua. Tomemos o exemplo do desafricamento da consoante africada palatal surda / $\mathfrak{t} /$ que ocorreu na evolução do Português. No Português Antigo, existia a oposição fonológica entre a fricativa palatal surda $/ \mathrm{J} /$, que era tradicionalmente grafada como $\langle\mathrm{x}\rangle$ (xadrez, graxa) e a africada palatal surda $/ \mathfrak{y} /$, grafada como $<\mathrm{ch}>$ (chão, chave). Esta oposição ficou na língua portuguesa até à metade do século XVII em que teve início o processo do seu desafricamento. Levou todo um século até esta transformação fonológica se consolidar no Português-padrão ${ }^{6}$, ou seja, nos dialetos centro-meridionais ${ }^{7}$ (Hricsina 2015: 166).

O plano linguístico que muda mais devagar é o subsistema morfossintático. Por exemplo, no Latim Vulgar, várias consoantes finais caíram e a oposição das vogais breves e longas deixou de ser pertinente; ${ }^{8}$ em consequência deste processo as formas casuais de nomes latinos foram sincretizadas. Esta evolução fonológica levou ao emprego obrigatório de várias preposições que começaram a exprimir as relações casuais que antes eram expressas por várias formas

5 Este tipo de orações é denominado relativas cortadoras (Mateus \& Cardeira 2007: 71).

6 Pelo Português-padrão entende-se geralmente "conjunto dos usos linguísticos das classes cultas da região LisboaCoimbra" (Cunha \& Cintra 1999: 10).

7 A oposição mencionada ainda persiste nos dialetos setentrionais do Português Atual (Raposo 2013: 99-100).

8 A neutralização da oposição entre as vogais breves e longas no Latim é tradicionalmente explicada pela mudança do tipo do acento que ocorreu no Latim Vulgar. O acento melódico, típico das fases anteriores da língua, transformouse no acento de intensidade (Zavadil 1998: 13). 
nominais. Com esta evolução, mudou também a ordem de palavras ( $\mathrm{S}-\mathrm{O}-\mathrm{V}>\mathrm{S}-\mathrm{V}-\mathrm{O})$. O subsistema nominal deixou de ser flexional e passou a ser analítico. Todo este processo era muito lento e levou vários séculos.

Outro princípio geral da mudança linguística baseia-se no facto de as línguas não mudarem num ritmo idêntico, mesmo sendo semelhantes, ou seja, pertencentes ao mesmo grupo linguístico (Zavadil 1998: 14-15). Se comparamos várias línguas românicas, ficamos a saber que cada língua tem evoluído com uma velocidade diferente. Observemos a evolução da palavra latina spatha em várias línguas românicas, respetivamente em Português, Castelhano e Francês. No

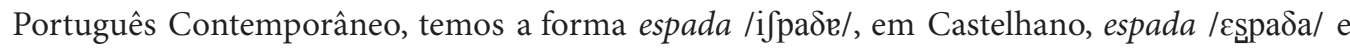
em Francês épée /epe/. Comparando esta palavra nestas línguas românicas, podemos constatar que a língua mais evoluída é o Francês em que na palavra a sibilante /s/ em coda já caiu e ocorreu também a síncope da oclusiva intervocálica /d/. Em Castelhano, a oclusiva intervocálica / $\delta /$ está enfraquecida e a sibilante /S / tende a cair nalgumas variedades geográficas do Espanhol (Andaluzia, algumas zonas da América Latina). Desta breve análise, podemos concluir que a evolução da palavra em questão foi mais rápida em Francês e mais lenta em Português.

Segundo outro princípio, o ritmo da evolução linguística é diferente em vários períodos da história duma língua. Cada língua passa por épocas relativamente estáveis ou tranquilas em que não ocorrem muitas mudanças no seu sistema linguístico e ao contrário, pode haver períodos relativamente turbulentos em que a língua muda rapidamente. Se tomarmos a evolução do Português, ficaremos a saber que os períodos turbulentos são representados pelos séculos XV e XVI (mudanças linguísticas que acompanham a passagem do Português Antigo ao Português Clássico) e pelo século XVIII em que ocorre uma série de mudanças linguísticas que transformaram o Português ao estado que conhecemos atualmente (redução das vogais tónicas, neutralização da oposição / $/ \mathrm{g} /: / \mathrm{J} /$, palatalização das sibilantes /s/ e /z/ em coda). Outros períodos da evolução da língua portuguesa eram relativamente estáveis.

Outra regra estabelecida pelos linguistas diacrónicos diz que cada mudança de língua tem os seus limites temporais, ou seja, pode afetar palavras duma língua apenas num período dado. Consideremos mais uma vez um exemplo do Português. Um dos traços típicos dos dialetos do noroeste da Península Ibérica (Português e Galego) é a queda das consoantes intervocálicas /l/ e /n/. Segundo os especialistas em questão, este processo operou-se no período compreendido entre os séculos IX e XI (Brocardo 2014: 97-101). As palavras que entraram nas línguas em questão antes ou dentro deste período, sofreram a mudança. Outras palavras que foram importadas a estas línguas num dos séculos posteriores, já não foram afetadas pelo processo mencionado. Consideremos a palavra portuguesa dor e o seu derivado doloroso. A palavra simples dor vem diretamente do Latim (door<dolore), enquanto que o seu derivado doloroso se formou num período posterior à base da palavra latina (dolorosus) e por isso já não foi afetado pela mudança. Achamos, porém, que a limitação temporal das mudanças linguísticas não é absoluta. Há vários fenómenos linguísticos que se repetem mais vezes na história duma língua. Apontar para alguns deles que ocorrem no Português e noutras línguas românicas é o objetivo principal deste artigo. 


\section{Evolução da verberante /r/ em posição implosiva}

No Português Antigo, havia duas líquidas alveolares: a verberante alveolar / / / e a vibrante múltipla alveolar /r/. Como verberante / $/$ / pronunciava-se o grafema simples <-r-> que se encontrava em posição intervocálica (caru->/karo/). Supõe-se que a vibrante alveolar múltipla /r/ se pronunciava nos contextos idênticos como na língua atual, ou seja, no início da palavra $<$ r- $>$, no caso do grafema dobrado <-rr- $>$ e depois de certas consoantes <-nr-, -sr-, -lr- $>$. Esta pronúncia é provada pela duplicação do grafema $<$ r $>$ que se pode encontrar em muitos documentos produzidos na época do Português Antigo: honrra, Isrrael ou rrainha. (Said Ali 2001: 40). Em consequência da queda das vogais /e, i/ finais antes das consoantes / $1, \mathrm{c}$, S / estabeleceu -se a verberante / / / também em posição final de palavra: amōre->/amor/. A oposição / / /:/r/ representava, assim, um dos traços típicos do Português até ao século XIX em que Gonçalves Viana, fundador da fonética científica em Portugal, regista em vários falantes lisboetas uma nova variante da vibrante múltipla /r/ que era realizada seja como vibrante uvular /R/, seja como fricativa velar /x/. A última pronúncia era mais rara (Viana 1973: 102). Vinte anos depois, o mesmo autor constata que o fenómeno se vai espalhando por outras regiões de Portugal.

No Português Contemporâneo o número de alofones é maior do que no século XIX. A variante que é a mais frequente e considerada padrão, é a fricativa uvular sonora /ь/ (Veloso 2015: 329). Outro traço caraterístico da pronúncia da verberante / $/$ / que se encontra em final de palavra, é o enfraquecimento ou a queda possível desta consoante: falar /fela(c)/ (Mateus 2004: 46). Uma reação possível dalguns falantes pode ser representada pela epítese da vogal central posterior /ì /: senhor /sinorì/. É um traço típico de certos dialetos portugueses (Tláskal 2006: 112). Outra reação possível ao enfraquecimento desta consoante pode ser representada por outra particularidade da pronúncia do $\mathrm{PE}^{9}$ : é a troca da verberante / $\mathrm{f} /$ pela verberante retroflexiva / $/$ / em final de sílaba ou de palavra em certos falantes (nomeadamente mulheres jovens) (Veloso 2015: 331-332). Vimos que a transformação do subsistema de verberantes e vibrantes no Português Contemporâneo é muito complexa e está longe de estar concluída.

A situação das verberantes e vibrantes no $\mathrm{PB}^{10}$ é ainda mais complicada do que no caso do PE. O PB contemporâneo conhece duas verberantes: uma é alveolar / / / e a outra retroflexiva /r/. Nos contextos em que no PE aparece a fricativa uvular sonora / $/$ / $(<\mathrm{r}->,<-$ rr- $>$, $<-$ nr-, - sr- , -lr- $>$ ) e também em posição implosiva, no PB podemos ouvir um leque de variantes, respetivamente: a fricativa velar /x/, a fricativa glotal /h/ ou a vibrante múltipla /r/. Tal como acontece no PE, também no PB estes alofones podem ser enfraquecidos ou podem cair no caso de se encontrarem em final de palavra: fazer /faze(r, x, h)/ (Mateus 2004: 46). Alguns linguistas veem nesta mudança de articulação um reforço da pronúncia da verberante / $\mathrm{f} /$ que tende a ser enfraquecida (Teyssier 2001: 83). A linguista finlandesa Iiris Rennicke vê, porém, nesta mudança de articulação o processo de enfraquecimento da pronúncia desta verberante $/ \mathrm{f} />/ \mathrm{x} />/ \mathrm{h} />/ 0 /$ (Rennicke 2011: 152).

Interessante é a evolução desta consoante noutras línguas românicas. Em termos gerais, podemos constatar que nelas se manifesta a mesma tendência como em Português, ou seja,

9 PE é a abreviatura que designa o Português Europeu.

10 PB é a abreviatura que representa o Português do Brasil. 
enfraquecimento da pronúncia da verberante / / / em final de sílaba ou de palavra. Este fenómeno pode-se encontrar em cada língua românica em períodos diferentes. No Italiano Antigo ocorreu a epítese da vogal /e/ em final de palavra provavelmente como reação dos falantes ao enfraquecimento da verberante final / $/$ /: mar>mare. No Catalão Antigo, a verberante / $/$ em final de palavra caiu: dormir/durmi/. Em Francês, a verberante / $/$ / caiu quase na totalidade de desinências nos séculos XV e XVI ${ }^{11}$. O processo de enfraquecimento desta consoante passou pela fase intermediária da sibilação: chaire >chaise. A mudança da articulação da verberante alveolar francesa / $\mathrm{f}$ / para a variante velar (uvular) /R/ que ocorreu nos séculos XIII e XVII, é tradicionalmente explicada como reação dos falantes ao processo de enfraquecimento desta consoante em certos contextos fonéticos (Zink 1994: 245).

Noutras línguas românicas, as tendências ao enfraquecimento da verberante $/ \mathrm{f} /$ ocorrem no presente. Como já vimos, é o caso do Português, mas também registamos este processo nalgumas variantes latinoamericanas do Espanhol. Eis alguns exemplos da evolução desta consoante: em Porto Rico, encontramos a lateralização da verberante / $/$ : venir /benil/; no Panamá, esta verberante que fica em final de palavra, cai: $m a r / m a /$; em Cuba, a verberante /s/ é aspirada em posição implosiva: sorpresa /sohpresa/; na República Dominicana, a consoante /r/ é vocalizada: cuerpo /kwejpo/; nas Caraíbas, deparamos com a sibilação da mesma consoante: carne /kasne/ (Vaquero de Ramírez 1996: 50-51).

Neste capítulo vimos que o fenómeno de enfraquecimento da verberante / $/ \mathrm{f}$ em final de sílaba e palavra afeta todas as línguas românicas em várias fases da sua evolução. Nalgumas delas o processo já foi concluído há muito tempo (Catalão, Francês), noutras esta transformação está em curso na atualidade (Português, Espanhol Americano e Castelhano falado na zona da Andaluzia). No Italiano, o processo que deve ter começado já na fase remota da sua evolução, foi bloqueado pela epítese da vogal /e/.

\section{Evolução da líquida lateral /1/ em posição implosiva}

Segundo os gramáticos latinos, a líquida lateral /l/ que se encontrava em final de sílaba ou de palavra ou antes de vogais exceto /i/, pronunciava-se duma maneira velarizada /1/ (Väänänen 1981: 63). Esta pronúncia é o primeiro passo para a vocalização possível desta consoante. Existem várias provas desta evolução no Latim: calculus $>$ cauculus, cauculator (em vez de calculator). Nos grupos /a/ + /l/ + /t, p, s / a líquida lateral /l/ foi vocalizada: altěru->/awtro/. Na segunda fase, o ditongo /aw/ foi alterado a /ow/ devido à assimilação à semivogal alta /w/: talparĭa-> /tawparja/>/towpajra/>/towpcjra/. Nalgumas palavras estes grupos foram, porém, conservados: altu->/ałto/, palpāre>/pałpar/. Supõe-se que há três fases da evolução possível da lateral /1/ neste contexto fonético: 1 . velarização /1/,2. vocalização /w/ e 3. queda /0/. Vimos que no Latim ou no Português Antigo, esta consoante teve evoluções diferentes em várias palavras.

No PE contemporâneo, a líquida lateral /// continua a pronunciar-se duma maneira velarizada nos contextos idênticos como no Latim Vulgar ou nas fases anteriores da evolução do Português: saltar /sałtar/, difícil /difisił/. Alguns falantes tentam reforçar a pronúncia desta consoante 
pela epítese da vogal central /ì / em final de palavra: sal /salì/. A lateral fica, assim, mais estável e não velariza. Evita-se, assim, a sua vocalização e queda potencial (Tláskal 2006: 55). A evolução desta consoante no PB atual é mais dinâmica do que no PE. A lateral /l/ nestes contextos fonéticos passa a ser vocalizada: saltar /sawtaR/, difícil /dififisiw/ ${ }^{12}$. Ainda por cima esta lateral pode cair em final de palavra: general /zenera/ e em final de sílaba pode ser trocada pela verberante /r/: alto /arto/ (Teyssier 2001: 82).

Se observarmos a evolução da lateral /1/ noutras línguas românicas, poderemos deparar com os processos idênticos ocorridos em várias épocas da evolução destas línguas. A tendência ao enfraquecimento do / / encontra-se por exemplo no Italiano Antigo em que um enfraquecimento possível desta consoante (em final de palavra) era provavelmente evitado pela epítese da vogal /e/ nas palavras monossílabas: mel>miele. Nas palavras com mais sílabas, a lateral /l/ caiu (provavelmente passando pelas fases intermediárias: velarização e vocalização): tribunal $>$ tribuna (Hamplová 2002: 50). Em Francês (língua românica mais progressiva), a vocalização da lateral velar /1/ em final de sílaba ocorreu já no século XI: /ałbe/>/aube/ (Zink 1994: 130). No Francês Contemporâneo, a lateral /l/ que fica em final de palavra, em muitas palavras não se pronuncia: gentil, outil, fusil. (Dohalská \& Schulzová 1991: 148). No Castelhano Antigo, esta consoante em final de sílaba pronunciava-se duma maneira velarizada: alto /atto/. Nalgumas palavras a lateral velar /1/ foi vocalizada: /ałtro/>/awtro/>/owtro/>/otro/ (Zavadil 1998: 186). No Castelhano Contemporâneo, a pronúncia desta consoante em posição implosiva costuma ser enfraquecida (Čermák 2005: 89).

Vimos que a consoante líquida lateral /l/ que se encontra em posição implosiva, tende à lenição da sua pronúncia de modo que é velarizada (na primeira fase) ou vocalizada (na segunda). Há casos em que esta consoante foi até suprimida (a terceira fase). Na nossa opinião, estamos, mais uma vez, perante um tipo de evolução linguística cíclica. Nalgumas línguas este processo foi concluído já na fase antiga da sua evolução (Francês, Italiano), noutras, a mudança começou há muitos séculos e tem continuado também atualmente (Castelhano, Português). Em cada língua o processo está em fase diferente da sua evolução (Castelhano - enfraquecimento da sua pronúncia; PE - velarização; PB - vocalização e queda).

\section{Evolução das oclusivas sonoras /b, d, g/ em posição intervocálica}

Uma das mudanças principais que afetou o sistema consonântico do Latim Vulgar foi a lenição das oclusivas sonoras /b, d, g/. As consoantes oclusivas /d/ e /g/ que se encontravam em posição intervocálica ${ }^{13}$, passaram a ser constritivas $/ \delta /$ e $/ \gamma /$. Em muitas palavras, estas novas constritivas caíram: estriga >/estriya/>/eștria/, $n \bar{u} d u->/$ nu $\delta$ //>/nuu/>/nu/. A evolução destas oclusivas no Português Antigo, porém, era diferente. Enquanto que a oclusiva alveodental /d/ caiu, seja já no Latim Vulgar, seja na fase inicial do Português Antigo, a oclusiva velar /g/, depois de ter sido fricativizada no Latim Vulgar, não caiu no Português Antigo. Pelo contrário, a sua queda eventual foi bloqueada pela reforço da sua pronúncia. A constritiva / / / voltou a ser oclusiva

12 Só no sul extremo do Brasil a vocalização não ocorre.

13 A consoante /g/ foi fricativizada quando precedida pelas vogais /a, o, $\mathrm{u} /$. 
/g/: $m a g u->/$ mago/>/mayo/>/mago/ ${ }^{14}$. A oclusiva bilabial sonora /b/ passou a ser constritiva / $/$ / para se tornar depois a labiodental sonora /v/ no Português Antigo: $f a b a>/ f a \beta a />/ f a v a /$.

No PE contemporâneo o processo da lenição das oclusivas sonoras repete-se. Do ponto de vista diacrónico, o fenómeno afeta dois tipos de consoantes: 1. as oclusivas latinas intervocálicas que se sonorizaram (no processo da lenição das oclusivas): pratu->/prado/; 2. as oclusivas sonoras latinas que depois da sua fricativização no Latim Vulgar foram reforçadas no Português Antigo: $\mathrm{magu}->/ \mathrm{mago} />/ \mathrm{ma \gamma o} />/ \mathrm{mago} /$. As oclusivas sonoras /b, d, g/ pronunciam-se, assim, como constritivas em posição intervocálica ou antes da líquida: lobo /lo $\beta \mathrm{u} /$, ida /i $\delta$ e/, magro /mayru/. No PE Contemporâneo, esta pronúncia é cada vez mais frequente, mas ainda não entrou no Português-padrão. Os dois alofones, quer dizer, as oclusivas /b, d, g/ e as constritivas $/ \beta, \delta, \gamma /$ podem ser realizados neste contexto (Tláskal 2006: 108-110) ${ }^{15}$. Acrescente-se que nalguns subdialetos do Português madeirense e açoriano, a lenição da pronúncia da oclusiva velar /g/ em posição intervocálica e precedida das vogais altas /i, u/ pode levar até à sua síncope: trigo /triu/ (Raposo 2013: 108, 114).

Noutras línguas iberorromânicas, respetivamente no Castelhano, Galego e Catalão, a pronúncia das oclusivas sonoras $/ \mathrm{b}, \mathrm{d}, \mathrm{g} /$ como constritivas $/ \beta, \delta$, $\gamma /$ é normativa. Nalgumas regiões hispanoamericanas registamos também a tendência forte à lenição destas oclusivas que leva, nalgumas variedades, à sua síncope: dedo /deo/ (Chile) (Vaquero de Ramírez 1996: 26-29). Em Francês, a evolução destas oclusivas era muito dinâmica. A oclusiva /b/ e constritiva /v/ caem já no século III: pavōre->/paor/>/peur/; a oclusiva velar/g/ no século V: secūru-> /segur/>/seyur/>/sewur/>/syr/ e a oclusiva alveodental /d/, depois da sua lenição que oco-

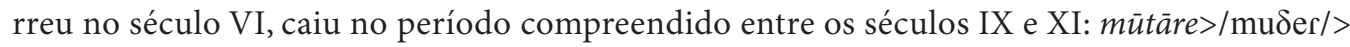
/myer/ (Zink 1994: 62, 111).

Vimos que, desde o período do Latim Vulgar, as oclusivas sonoras /b, d, g/ em posição intervocálica ou antes da líquida têm tendido à lenição que pode causar também a sua síncope. Ao contrário, em vários casos, a pronúncia das oclusivas lenizadas pode ser reforçada para se evitar a sua queda. Em Francês, as duas tendências ocorreram muito cedo e as oclusivas caíram em muitas palavras. Nas línguas iberorromânicas, a evolução não era tão dinâmica. As oclusivas que foram lenizadas no Latim Vulgar e não caíram, foram reforçadas nas fases iniciais da evolução destas línguas. As tendências à sua lenição, porém, voltaram e as oclusivas passaram a ser constritivas (Castelhano, Galego, Catalão) ou eventualmente tendem a ser pronunciadas deste modo (PE). Nalgumas variantes isoladas destas línguas esta fricativização pode levar até à sua síncope (dialetos madeirenses ou açorianos e Espanhol Latinoamericano).

14 Nalgumas palavras a oclusiva /g/ caiu já no Latim Vulgar e no Português Antigo não foi restituída: ĕgo $>/ \varepsilon y o />/$ eo/>/ew/, legāle $>/$ leyal/>/leał/.

15 Segundo outros autores, este fenómeno é tão generalizado que já pode ser considerado pertencente ao Portuguêspadrão (Barbosa 1994: 60; Barroso 1999: 95-97). 


\section{Evolução da sibilante /s/ em final de palavra}

No Latim, o destino da sibilante $/ \mathrm{S} /{ }^{16} \mathrm{em}$ final de palavra dependia de vários fatores: do contexto fonético em que se encontrava, dos fatores morfológicos e também geográficos. A sibilante /s / caía por exemplo na desinência - us seguida duma outra consoante. Em muitas formas nominais a sua apócope foi bloqueada pelo papel importante que ela tinha na declinação nominal. No que diz respeito ao tratamento desta sibilante em final de palavra, a România está dividida em duas partes opostas: a România ocidental (Português, Castelhano, Catalão, Francês etc.) manteve o /s / final e na România oriental (Italiano, Romeno) ocorreu a sua apócope. Nesta parte da România o /S / final foi substituído parcialmente pela vogal /i/: cantas>canti (Väänänen 1981: 67-68) ${ }^{17}$. Em Português, a evolução do subsistema de sibilantes era muito complexa. No Português Antigo, havia a oposição de dois pares de sibilantes: apicoalveolares /S/:/Z/ e africadas alveolares /ts/:/dz/. Segundo os especialistas em questão, já no século XIII as africadas alveolares começaram a perder a parte oclusiva /t/ e /d/ e passaram a ser as sibilantes predorsodentais /s/ e /z/. No século XVI esta oposição correlativa de sibilantes foi neutralizada no Português-padrão (dialetos centro-meridionais) e as variantes apicoalveolares desapareceram ${ }^{18}$. Em final de palavra podem ter aparecido só a sibilante apicoalveolar /s / que se tornou predorsodental /s/ e africada alveolar /dz/ que se tornou sibilante predorsodental sonora /z/: amicos >/amigos / /amigos/; ŭ̌ce->/vedz/>/vez/. No século XVIII, as duas sibilantes em posição implosiva foram palatalizadas, ou seja, começaram a pronunciar-se como fricativa prepalatal / $/$ : /amigos/>/amigo $/$, / vez/>/ve $\int /$. Esta mudança terá sido motivada pela fusão provável das duas sibilantes /s/ e /z/ em posição implosiva (Castro 2006: 199).

Enquanto que no PE contemporâneo a posição desta fricativa é relativamente estável, provavelmente devido ao reforço da pronúncia da sibilante original /s/, no PB em que a palatalização do /s/ não ocorreu, a sibilante /s/ em final de palavra tende a ser suprimida em várias regiões. A apócope do /s/ final está relacionado com fatores morfológicos. Em Santa Catarina e no Rio Grande do Sul, a sibilante cai frequentemente nos verbos que ficam na segunda pessoa do sg.: tu canta, tu cantava. No dialeto Caipira e em Minas Gerais, o /s/ final cai geralmente nos nomes no plural: os livro, as coisa, as mulher. Este fenómeno tem as consequências para a estrutura morfológica dos verbos e nomes no PB. O plural exprime-se, assim, só por meio da forma do artigo. (Raposo 2013: 151).

Um fenómeno semelhante (enfraquecimento da sibilante /s/ em final de palavra) pode ser encontrado nalgumas variedades da língua espanhola atual: é na Andaluzia ou nas Caraíbas em que o/s/ final tende à apócope. Nas Caraíbas deparamos com uma fase intermediária,

16 Supõe-se que a sibilante latina /s/ era apicoalveolar /s /. Esta consoante manteve com certeza a sua pronúncia apicoalveolar nas fases antigas das línguas iberorromânicas (Zavadil 1998: 156-157)

17 Alguns especialistas opinam que a apócope do /s / final nas línguas românicas orientais tem origem no facto de ter predominado a língua popular em Italiano e Romeno, enquanto que em oeste da România se utilizava uma língua escolar (Hamplová 2002: 51). Esta opinião, porém, não é unânime (cf. Väänänen 1981: 68).

18 No norte de Portugal a situação é diferente. Na Beira e no Minho litoral, a neutralização da oposição de sibilantes produziu-se em favor das variantes apicoalveolares. Na região de Trás-os-Montes e numa parte da Beira Alta, a oposição antiga de dois pares de sibilantes foi conservada até hoje. 
representada pela realização fricativa glotal /h/, entre a pronúncia da sibilante /s/ e a sua queda: /s/>/h/>/0/: vamos /bamoh/, los libros /loșlißro/ (Čermák 2005: 109-111).

$\mathrm{Na}$ fase antiga do Francês, a sibilante /s/ em posição implosiva foi conservada. No entanto, no período compreendido entre os séculos XI e XIII esta consoante caiu, provavelmente com uma fase intermediária representada pela fricativa uvular $/ \chi /: b \bar{a} s s u->/$ bas $/>/$ ba $/>/$ ba/ (Zink 1994: 79-80).

Também no caso da sibilante /s/ em final de palavra encontramo-nos perante uma evolução cíclica. Vimos que esta consoante tendia a ser suprimida já nalgumas variedades do Latim Vulgar (nas regiões orientais). Nas outras variantes em que o /s/ final não caiu, o processo do seu enfraquecimento se repetiu na evolução seguinte destas línguas. No caso do Francês, a evolução foi muito rápida e o /s/ em posição implosiva caiu já no período compreendido entre os séculos XI e XIII. Em várias variedades dalgumas línguas iberorromânicas, podemos deparar com o mesmo fenómeno atualmente (Espanhol falado na zona das Caraíbas e na Andaluzia e nalguns dialetos do $\mathrm{PB}$ ).

\section{Evolução da consoante nasal /n/ em posição intervocálica}

O último capítulo desta artigo é dedicado a um fenómeno que é típico das línguas que se formaram no noroeste da Península Ibérica, ou seja, do Português e Galego. É a síncope da consoante nasal /n/ em posição intervocálica. Supõe-se que este processo terá começado no século X e no século XII ainda não estaria concluído (Mattos e Silva 2006: 69). Segundo a mesma autora a síncope da consoante nasal teria ocorrido da seguinte maneira: primeiro a consoante /n/ caiu e deixou a sua nasalidade na vogal precedente que influenciou a vogal seguinte ao nasalizá-la: bono $>/$ boo/>/bõo/>/bõõ/, tener $>/$ teer/>/tẽer/>/tẽẽr/ (Mattos e Silva 2006: 70). Na nossa opinião, o processo pode ter ocorrido duma maneira um pouco diferente: primeiro a consoante /n/ pode ter nasalizado a vogal precedente, a sua nasalidade pode ter causado a queda da consoante e a primeira vogal nasal terá nasalizado a vogal seguinte: bono $>/$ bõno/>/bõo/>/bõõ/, tener $>/$ tẽner/>/tẽer/>/tẽẽr/.

No PB contemporâneo encontramos um fenómeno muite semelhante ao que acabamos de descrever, ou seja, a nasalização da vogal que precede uma consoante nasal intervocálica /n, m, n/: ano /ẽnu/ (Bechara 2009: 64). Alguns linguistas consideram este fenómeno como um traço arcaico do PB (Cuesta \& Luz 1980: 220). Levando em conta os factos acima expostos, não nos encontraremos também neste caso perante uma mudança cíclica? Não representará esta nasalização da vogal antes da consoante nasal intervocálica só o primeiro passo em direção ao enfraquecimento da consoante ou à sua síncope seguinte? Achamos que esta eventualidade não está excluída.

\section{Conclusões}

Neste estudo apresentámos cinco mudanças linguísticas que na nossa opinião representam uma evolução cíclica, ou seja, que se repetem na história de várias línguas românicas. Primeiro analisámos a evolução da vibrante /r/ e verberante / / /, vendo que o subsistema destas consoantes está 
a mudar sensivelmente tanto no PE quanto no PB atuais. Continuámos com a análise da consoante lateral /l/ que se vê enfraquecida em posição implosiva em ambas as variantes do Português Contemporâneo, sendo no $\mathrm{PB}$ a sua evolução mais progressiva. Seguiu-se o capítulo dedicado à evolução das oclusivas sonoras /b, d, g/ cuja lenição voltou a aparecer no PE atual. Este processo já ocorreu ou foi concluído noutras línguas românicas num período mais remoto. Depois passámos a analisar a evolução da sibilante /s/ em final de palavra que desapareceu em várias línguas românicas já muito cedo na sua história. No PB atual e nalgumas variantes do Espanhol este processo está a ocorrer na atualidade. Acabámos por ocupar-nos dum fenómeno peculiar das línguas nascidas no noroeste da Península Ibérica, isto é, da síncope da consoante nasal intervocálica /n/. Apontámos para uma possibilidade da volta deste processo no PB atual.

\section{Referências bibliográficas}

Barbosa, J. M. (1994). Fonologia e Morfologia do Português. Coimbra: Almedina.

Barroso, H. (1999). Forma e substância da expressão da língua portuguesa. Coimbra: Almedina.

Bechara, E. (2009). Moderna gramática portuguesa. Rio de Janeiro: Editora Nova Fronteira.

Brocardo, M. T. (2014). Tópicos de História da Língua Portuguesa. Lisboa: Edições Colibri.

Castro, I. (2006). Introdução à História do Português. Lisboa: Edições Colibri.

Cuesta, P. V., \& Luz, M. A. M. da (1980). Gramática da Língua Portuguesa. Lisboa: Edições 70.

Cunha, C., \& Cintra, L. F. L. (1999). Nova Gramática do Português Contemporâneo. Lisboa: João Sá da Costa.

Čermák, P. (2005). Fonetika a fonologie současné španělštiny. Praha: Karolinum.

Dohalská, M., \& Schulzová, O. (1991). Fonetika francouzštiny. Praha: Karolinum.

Hamplová, S. (2002). Nástin vývoje italského jazyka. Praha: Karolinum.

Hricsina, J. (2015). Vývoj portugalského jazyka. Praha: Karolinum.

Margarit, A. M. B. (1985). Gramática catalana I, II. Madrid: Gredos.

Martins, A. M. (2002).Variação e Mudança no Português. In A Língua Portuguesa: Actas dos IX cursos internacionais de Verão de Cascais - 2002 (pp. 29-44). Cascais: Câmara Municipal de Cascais \& Instituto de Estudos Sociais.

Mateus, M. H. M. et al. (2004). Gramática da língua portuguesa. Lisboa: Caminho.

Mateus, M. H. M., \& Cardeira, E. (2007). Norma e variação. Lisboa: Caminho.

Mattos e Silva, R. V. (2006). O português Arcaico fonologia, morfologia e sintaxe. São Paulo: Editora Contexto.

Mattoso Câmara Jr., J. (1975). História e estrutura da língua portuguesa. Rio de Janeiro: Padrão.

Peres, J. A., \& Móia, T. (1995). Áreas críticas da Língua Portuguesa. Lisboa: Caminho.

Raposo, E. P. et al. (2013). Gramática do Português - Volume I. Lisboa: Fundação Calouste Gulbenkian.

Rennicke, I. (2011). The retroflex r of Brazilian Portuguese: theories of origin and a case study of language attitudes in Minas Gerais. In Revista de Estudos Linguísticos da Universidade do Porto, 6, 149-170.

Said Ali, M. (2001). Gramática Histórica da Língua Portuguesa. São Paulo: Editora Melhoramentos.

Silveira Bueno, F. da (1955). A Formação histórica da língua portuguesa. Rio de Janeiro: Livraria Acadêmica.

Šabršula, J. et al. (1980). Úvod do srovnávacího studia románských jazyků I-II. Praha: SPN.

Teyssier, P. (2001). História da Língua Portuguesa. Lisboa: Sá da Costa.

Tláskal, J. (2006). Fonetika a fonologie současné evropské portugalštiny. Praha: Karolinum. 
Vaquero de Ramírez, M. (1996). El español de América I. Pronunciación. Madrid: Arco Libros.

Väänänen, V. (1981). Introduction au latin vulgaire. Paris: Klincksieck.

Veloso, J. (2015). The English $r$ coming! The never ending story of Portuguese rhotics. In A. Simões, A.

Barreiro, D. Santos, R. Sousa-Silva, \& S. E. O. Tagnin (Eds.), Linguística, Informática e Tradução: Mundos que se Cruzam (vol. 7) (pp. 323-336). Oslo: Studies in Language.

Viana, A. d. R. G. (1973). Estudos de Fonética Portuguesa. Lisboa: Imprensa Nacional - Casa da Moeda. Williams, E. B. (1986). Do Latim ao Português. Rio de Janeiro: Tempo brasileiro.

Zavadil, B. (1998). Vývoj španělského jazyka I. Praha: Karolinum.

Zink, G. (1994). Phonétique historique du français. Paris: Presses Universitaires de France. 